\title{
PERSEPSI NETIZEN TERHADAP POLA PEMBERITAAN LAMBE TURAH SEBAGAI STRATEGI KOMUNIKASI DALAM PERSPEKTIF FILSAFAT SOSIAL
}

\author{
Aisyah Abbas ${ }^{1}$, Fatimatuz Zahra ${ }^{2}$, Rofi ${ }^{3}$ \\ Universitas Gadjah Mada; Aisyahabbas23497@ gmail.com ${ }^{1}$ \\ Universitas Gadjah Mada; zahrafatimatuz17@gmail.com² \\ Universitas Gadjah Mada; rofi2sukses123@ gmail.com³
}

\begin{abstract}
ABSTRAK
Komunikasi telah memasuki babak baru dalam perkembangannya, yaitu era komunikasi kontemporer. Hal ini mengakibatkan berubahnya arus informasi yang satu arah dan dikuasai oleh pemegang oto ritas menjadi sangat meluas sehingga siapapun dapat menjadi media komunikasi dan informasi. Namun hal ini bukan tanpa cela, arus komunikasi yang serba bebas menuntut setiap individu memiliki preferensi terhadap suatu media. Di sisi lain, media-media non jurnalis termasuk lambe turah mendapatkan lahan seluas-luasnya untuk meraih simpati dan membentuk persepsi suatu kelompok masyarakat. Lambe turah hadir dengan aturan yang lebih fleksibel sehingga informasi dapat dengan cepat dipublikasikan meskipun degan kelemahan minim verifikasi. Media Lambe Turah memunculkan konsep Netizen Jurnalizm sebagai penyampai informasi dengan cepat. Perangkat yang dimiliki Netizen dianggap telah memenuhi tata cara pendokumentasian dan pelaporan langsung dari suatu kejadian. Penelitin ini menggunakan metode kualitatif dengan menggunakan sudut pandang filsafat sosial filsafat komunikasi berusaha memahami jalannya proses komunikasi serta efektivitas strategi penyampain informasi dan komunikasi kontemporer. Hasil dari penelitian ini diharapkan dapat digunakan untuk memanfaatkan pengaruh persepsi netizen dalam strategi komunikasi kontemporer.
\end{abstract}

Kata kunci : strategi komunikasi kontemporer, persepsi netizen, lambe turah

\begin{abstract}
Communication has entered a new phase in its development, namely the era of contemporary communication. This has resulted in changes in the flow of information that is one-way and controlled by the authorities to be very widespread so that anyone can become a medium of communication and information. But this is not flawless, the free flow of communication requires every individual to have a preference for a media. On the other hand, non-journalist media including lambe-turah get the widest possible land to gain sympathy and shape the perceptions of a community group. Lambe Turah comes with more flexible rules so that information can be quickly published even with minimal verification weaknesses. Lambe Turah's media gave rise to the concept of Netizens Netizens as fast-forwarders of information. Devices owned by Netizens are deemed to have met the procedures for documentation and direct reporting of an event. This research uses qualitative methods using the viewpoint of social philosophy of communication philosophy trying to understand the course of the communication process and the effectiveness of contemporary information and communication delivery strategies. The results of this study are expected to be used to utilize the influence of netizen's perceptions in contemporary communication strategies.
\end{abstract}

Keywords: communication strategy, netizens, lambe turah 


\section{PENDAHULUAN}

Viral dalam Kamus Besar Bahasa Indonesia (KBBI) daring, berarti segala sesuatu yang bersifat meluas seperti virus (Bahasa, 2016). Term viral belakangan mulai menggantikan makna dari terkenal atau diketahui oleh banyak orang. Terminologi viral juga sering kali diidentikkan dengan peran sosial media sebagai sarana terciptanya kondisi viral tersebut, karena dengan masifnya penggunaan media sosial maka konsekuensinya penyebaran suatu informasi akan lebih cepat dan meluas, dan inilah yang dinamakan viral (Sari, 2016). Dalam literatur yang lain juga disebutkan bahwa viral adalah kependekan dari virus virtual, yaitu sesuatu yang menyebar luas secara cepat seperti virus namun hanya terbatas pada ruang-ruang yang virtual.

Fenomena viral belakangan ini diantaranya adalah munculnya idol-idol yang memulai kepopulerannya dari media sosial seperti awkarin, bowo, ria ricis, dan lain- lain (Kurniawan, 2016). Mereka dikatakan viral karena mampu melahirkan konten- konten yang menyebar luas secara cepat di dunia virtual. Bukan hanya individu- individu yang memiliki keunikan sehingga banyak disoroti oleh netizen yang menjadi viral, trend media pemberitaan dengan gaya yang tidak biasa juga mulai diminati. Lambe turah adalah salah satu pioneer platfoam pemberitaan yang berbasis dari dan untuk netizen (Febrianto, 2017). Akun Lambe Turah lahir sejak tahun 2016 dengan memberikan penekanan fokus konten akunnya pada topik dunia hiburan (Prajarto,2018), Serta menampilkan unggahan berita secara sederhana seperti yang dilakukan Lambe Turah pada insiden bianglala di sekaten yang turut membuatnya viral, selain itu berbagai kejadian seperti kecelakaan, insiden juga turut dirilis dalam akun Lambe Turah.

Lambe turah hadir dengan aturan yang lebih fleksibel sehingga informasi dapat dengan cepat dipublikasikan meskipun degan kelemahan minim verifikasi. Media Lambe Turah memunculkan konsep Netizen Journalism sebagai penyampai informasi dengan cepat. Perangkat yang dimiliki Netizen dianggap telah memenuhi tata cara pendokumentasian dan pelaporan langsung dari suatu kejadian (Mabweazara, 2011). Meski demkian, melihat minat netizen terhadap pemberitaan lambe turah terindikasi bahwa model penyampaian unggahan berita Lambe Turah dengan minim caption dan membiarkan berkembangnya wacana oleh netizen secara mandiri menjadikan informasi yang disampaikan Lambe Turah Viral dengan cepat. Selain itu, isu kontroversial justru lebih diminati oleh netizen, serta sense of belong netizen dalam menerima informasi dari Lambe Turah lebih kuat dibandingkan dengan partisipasnya dengan media konvensional (Prajarto, 2018 )

Bagaikan pisau bermata dua, hal tersebut dapat menjadi strategi komunukasi yang efektif apabila dapat dipertanggungjawabkan, namun juga dapat menjadi sumber tubir apabila yang disebarkan mengandung probabilitas yang tinggi terhadap berbagai kemungkinan. Lambe Turah lebih tepat menjadi ruang interaksi bagi setiap netizen dalam mengolah data atau informasi dengan dibarengi bukti konkret. Oleh karena itu,peniliti menganggap bahwa pengkajian lebih lanjut tentang strategi komunikasi yang digunakan oleh Lambe Turah serta pengaruhnya terhadap minat netizen, merupakan penelitian yang penting untuk dilaksanakan. Sudut pandang filsafat menjadi dasar analsisi dalam menelisik lebih dalam tentang persepsi netizen terhadap informasi yang disampaikan oleh Lambe Turah. Artikel ini akan lebih jauh membahas mengenai pengaruh aktivitas akun lambe turah di media sosial terhadap persepsi masyarakat, dan bagaimana tinjauan filsafat terhadap fenomena tersebut. 


\section{METODOLOGI PENELITIAN}

Perspektif yang digunakan dalam penelitian ini, adalah filsafat sosial. Yaitu dengan meneliti pandangan dasar kelompok atau dalam salah satu fenomena sebagai keyakinan-keyakinan tentang strukutur-struktur dan kaindah-kaidah yang mengatur seluruh hidup mereka, dan yang menyangkut hakikat manusia, dunia dan Tuhan (Anton Bakker, 1990). Lebih khusunya filsafat komunikasi karena filsafat komunikasi berusaha memahami jalannya proses komunikasi serta efektivitas strategi penyampain informasi.

Masyarakat sebagai struktur sosial yang di dalamnya mencangkupi hubungan atau interaksi antara individu dengan kelompok (Soekanto 1969). Habermas merumuskan bahwa transformasi sosial tidak dilakukan dengan cara yang revolusioner, tetapi dengan "dialog emansipatoris", Dengan komunikasi yang tanpa penguasaan (Hardiman, 2007). Melalui komunikasi itulah manusia dapat mencapai kesaling pemahaman. Oleh karenanya penting untuk merencanakan masa depan, yang baik, dan yang benar dengan komunikasi. Habermas menemukan bahwa sifat dasar bahasa sebagai sarana komunikasi terdapat dalam pengertian baik pembicara maupun pendengar suatu percakapan secara apriori berminat untuk saling memahami (Lechte,2004). Habermas memperlihatkan bahwa tujuan ilmu-ilmu kritis dengan tujuan emansipatorisnya membantu masyarakat untuk mencapai otonomi dan kedewasaan (Mündigkeit).Ia juga menunjukkan bahwa otonomi kolektif ini berhubungan dengan konsensus bebas dominasi.

Hingga tahun 80-an, dia mengandaikan konsensus semacam itu dapat dicapai dalam sebuah masyarakat yang reflektif (cerdas) yang berhasil melakukan komunikasi dengan mencapai 'klain-klaim kesahihan'(validity claims). Klaim-klaim inilah yang dipandang rasional dan akan diterima tanpa paksaan sebagai hasil konsensus. Dalam The Theory of Communicative Action, Habermas menyatakan ada empat macam klaim, yakni:

1) klaim kebenaran (truth) yakni kesepakatan tentang dunia alamiah dan objektif

2) klaim ketepatan (rightness) yakni kesepakatan tentang norma-norma dalam dunia social

3) klaim autensitas atau kejujuran (sincerity) yakni kesepakatan tentang kesesuaian antara dunia batiniah dan ekspresi seseorang

4) klaim komprehensibilitas (comprehensibility) dicapai apabila kita telah mencapai kesepakatan klaim-klaim di atas. Setiap komunikasi yang efektif harus mencapai'kompetensi komunikatif' tersebut.

Masyarakat komunikatif bukanlah masyarakat yang berkomunikasi dengan kekerasan, melainkan lewat 'argumentasi'. Habermas membedakan argumentasi menjadi diskursus/perbincangan(discourse) dan kritik. Meskipun dimaksudkan untuk konsensus, komunikasi juga bisa terganggu, sehingga kita tak perlu mengandaikan konsensus. Dalam hal ini, Habermas berbicara tentang kritik. Ada dua macam kritik, yakni 'kritik estetis' yang mempersoalkan kesesuaiannya dengan penghayatan dunia batiniah dan 'kritik terapeutis', yakni menyingkapkan penipuan-diri masing-masing pihak yang berkomunikasi (Habermas 1987).

Perspektif ini digunakan karena peneliti ingin mencari dan menemukan landasan filosofis yang menjadi kerangka dasar dalam peristiwa viralnya berita di media lambe turah serta menganalisis persepsi netizen terhadap pemberitaan di lambe turah. 
Untuk menemukan informasi tentang strategi pemberitaan serta pembentukan persepsi netizen, peneliti menggunakan teknik wawancara secara mendalam. Hubungan antara peneliti dengan para informan harus dibuat akrab, sehingga subjek penelitian bersikap terbuka dalam menjawab setiap pernyataan (Hamidi, 2008). Untuk mengaplikasikan metode ini peneliti akan masuk pada komunitas-komunitas yang terkait dengan regulasi pemberitaan media lambe turah.

Teknik kedua yang digunakan dalam penelitian ini adalah observasi terhadap perilaku atau tindakan baik dalam bentuk verbal, non verbal dan aktivitas individual mereka dalam kelompok (Hamidi, 2008). Teknik ini diwujudkan dengan cara memantau sikap dan tanggapan netizen di sosial media maupun secara lansung terhadap berita yang disebar luaskan oleh lambe turah.

Teknik ketiga adalah menggunnakan teknik informasi dokumentasi, untuk mengumpulkan informasi tentang langkah-langkah penyebarluasan informasi yang dilakukan oleh pemegang otoritas dalam akun lambe turah serta segmentasi pembaca dan opini yang ingin digiringnya. Sumber informasi dokumentasi ini adalah semua literatur yang mendukung kegiatan penelitian. Dokumen ini dapat berwujud informasi dari media dan dokumentasi pribadi peneliti.

Keseluruhan jumlah dan kriteria informan penelitian ditetapkan dengan menggunkaan teknik snow-ball sampling, yakni penggalian data melalui wawancara mendalam terhadap responden yang memenuhi kriteria, dari satu responden ke responden lainnya (Hamidi, 2008). Teknik snow-ball sampling membantu peneliti untuk mengarahkan kriteria nasarumber berdasarkan informasi yang diperoleh dari narasumber sebelumnya sehingga permasalahan tidak melebar dan mendapatkan informasi yang cukup terkait tema penelitian (Prof. Dr. Nyoman Kutha Ratna, 2016)

\section{HASIL DAN PEMBAHASAN}

\section{Mengenal lambe turah}

Lambe turah berasal dari bahasa jawa yang merupakan gabungan dari kata "lambe" yang berarti bibir/mulut dan "turah" yaitu sisa, yang digunakan untuk menggambarkan kondisi kegemaran bergunjing bagaikan punya jatah mulut atau lambe yang berlimpah sehingga dan tersisa untuk membicarakan orang lain. Lambe turah kemudian digunakan menjadi nama sebuah pelopor akun gosip di sosial media. Akun lambe turah yang eksis di sosial media dengan jumlah folowers tak kurang dari 6 juta pengguna akun instagram ini telah berdiri dan dikembangkan sejak tahun 2015 .

Lambe Turah berhasil merebut ceruk pasar gosip yang sangat besar di Indonesia. Tayangan infotainment di televisi selama sekian tahun rating tinggi. Di Tanah Air, sudah ada akun anonim legendaris lainnya yang pernah mengalami kejatuhan: @ TrioMacan2000. Lambe Turah seakan-akan merupakan reinkarnasi Triomacan, akun Twitter yang pernah menggemparkan Indonesia karena melempar tudingan korupsi, maupun berbagai isu politik, menyerang baik Presiden SBY maupun Presiden Joko Widodo. (Wirgadireja, 2017)

Menurut survey yang kami lakukan pada lebih dari 110 responden, $70 \%$ mengatakan bahwa akun lambe turah memiliki ciri khas yang unik dibandingkan dengan akun-akun berita maupun gosip lainnya. Lambe turah menerapkan sistem penyampaian informasi secara anonim atau menyembunyikan pihak yang menyampaikan informasi. Bahkan, dilansir dari tirto.id admin akun tersebut harus bersembunyi di toilet untuk melakukan proses unggah konten. Hal tersebut dilakukan untuk menjaga kerahasiaan admin akun 
lambe turah ini. Selain anonim, ciri lain yang melekat dari akun ini ialah paparazi atau pengambilan gambar/rekaman yang dilakukan tanpa izin subjekyang bersangkutan. Pada bagian inilah eksistensi lambe turah sering kali menuai pro dan kontra karena dianggap melanggar privasi orang lain. Kendati demikian, popularitas akun lambe justru kian meroket dibuktikan dengan bertambahnya jumlah folowers akun tersebut.

Akun lambe turah meskipun menuai kritik, tetapi juga mewadahi kreativitas masyarakat/warganet dalam membuat konten yang menarik. Dalam wawancara eksklusif yang dilakukan oleh tirto.id, admin akun lambe turah mengkonfirmasi bahwa pihaknya menerima masukan konten dari warga net asalkan disertai dengan bukti yang kuat. Bisa berupa foto, video ataupun rekaman suara. Hal inilah yang berperan menarik simpati masyarakat untuk berpartisipasi memberitakan sesuatu. Meskipun sesungguhnya tren seperti ini (citizen journalism) bukan lagi hal yang baru, namun dalam pemberitaan gosip melalui sosial media yang cenderung santai dan tidak banyak kriteria seperti halnya media mainstram pada umumnya tentu saja menjadi sebuah daya tarik tersendiri.

Berkenaan dengan anonimitas, kami telah melakukan wawancara kepada bapak Ferdinandus Saetu selaku kepala biri humas kemkominfo sekaligis timpenyusun UUITE. Beliau mengatakan bahwa anonimtas bukanlah sesuatu yang perlu dikhawatirkan, justru hal ini merupakan ciri utama dalam sebuah transformasi digital. Sebuah pengejawantahan dari kebebasan berpendapat dan pereskprsi yang telah termaktub dalam UUD 1945 pasal 28E. Namun tidakserta merta anonimitas lepas dari tanggung jawab, ketika telah menyinggung SARA, usaha penipuan dan hal-hal lain yang telah diatur dalam UUITE maka kominfo dan kepolisian berhak dan sanggup untuk melacak akun tersebut sekalipun anonim. (Setu, 2019)

Beliau juga mengatakan bahwa kita tidak dapat serta merta membendung arus informasi, justru yang dapat kita lakukan adalah memilah informasi. Belum dapat dipastikan bahwa 6 juta pengikut lambe turah adalah 6 juta orang yang percaya dengan informasi lambe turah tanpa menimbang dari media massa ataupun media mainstream lainnya. Beliau juga optimis bahwa masyarakat berangsur akan mampu memilah informasi mana yang lebih mereka butuhkan.

Namun fakta yang kami temukan di lapangan, $40 \%$ pembaca lambe turah merasa terprovokasi oleh berita yang disebarkan oleh lambe turah. Selain itu, media-media gosip baik cetak maupun online yang secara legal terafiliasi dengan dewan pers pun mengatakan bahwa mereka tidak menolak informasi dari lambe turah untuk dijadikan sebagai bahan penulisan sebuah berita. Misalnya yang dilakukan oleh kapanlagi.com, sebuah situs berita entertainment yang menduduki peringkat 13 dalam indeks pencarian website di Indonesia, mereka secara terang-terangan mengakui bahwa informasi yang bersumber dari lambe turah ataupun akun gosip anonim lainnya dapat mereka jadikan sumber awal ataupun mereka kutip dalam badan informasi. Secara linear, dapat disimpulkan bahwa lambe turah memiliki tingkat kepopuleran yang tinggi tidak hanya pada kalangan awam namun juga para pegiat jurnalisme, sekalipun lambe turah sama sekali bukan media jurnalis.

\section{Persepsi Netizen terhadap Lambe Turah}

Eksistensi akun Lambe Turah tidak lepas dari besarnya pengikut dan respon yang ditunjukkan oleh netizen akun Lambe Turah. Sampai detik ini, jumlah pengikut lambe turah di Instagram telah lebih dari 6,6 juta orang. Tingginya pengikut lambe turah dibanding dengan akun-akun gosip lain seperti Lambe Nyinyir, Tante Rempong, Lambe Corner, Lambe Lamis, serta akun media massa digital seperti Tirto.id, TribunNews, 
Vice, dan kampuran menunjukkan akun Lambe Turah mendapat tempat tersendiri dimata mayarakat sebagai akun yang dapat menyebarkan informasi dengan cepat dan terkini, khususnya yang berkaitan dengan kehidupan publik figur. Untuk memahami lebih jauh tentang persepis netizen terhadap lambe turah, penulis melakukan survey pendapat masyarakat umum secara online dengan jumlah responden sebanyak 110 orang. Rentang usia 18-32 tahun sebanyak 71,8\% jumlah responden secara keseluruhan yang mengetahui dan mengikuti informasi dari lambe turah. Data ini dapat diartikan bahwa jumlah pengikut lambe turah didominasi oleh usia muda.

Informasi yang disajikan oleh lambe turah menjadi konsentrasi utama bagi para netizen sebagai asupan untuk bergosip maupun pengetahuan tentang informasi terbaru, meskipun informasi yang disajikan lebih banyak tidak sesuai dengan kebutuhan informasi masyarakat. Hal ini terbukti sebanyak 27,3\% dengan jumlah 30 orang tidak setuju jika akun lambe turah dianggap sebagai akun yang telah menyajikan informasi sesuai dengan kebutuhan masyarakat. Akan tetapi pada posisi kedua dengan jumlah prosentasi 25,5\% memilih untuk netral terkait informasi lambe turah telah mengakomodir kebutuhan masyarakat atau belum. Dilanjutkan dengan posisi ketiga sebanyak 20,9\% menunjukkan keberpihakan netizen yang menganggap bahwa kebutuhan informasi masyarakat telah ada dan tersalurkan melalui lambe turah. Di era modern saat ini berlimpahnya informasi di kalangan masyarakat menjadi bahan analisis sesuai dengan kebutuhan masing-masing. Masyarakat cenderung tertarik pada isu tertentu dan media yang memiliki kredibilitas untuk dan dipercaya informasinya (Setu, 2019).

Penyajian informasi yang disampaikan oleh Lambe Turah berhasil menarik perhatian netizen untuk melihat lebih jauh, $76,4 \%$ dari jumlah keseluruhan responden menganggap konten lambe turah telah sesuai dengan ketertarikan masyarakat. Tingginya responden yang menganggap konten lambe turah sesuai dengan ketertarikan masyarakat menjadikan informasi yang disampaikan oleh Lambe Turah selalu mendapat perhatian tinggi oleh publik dan berujung pada viralnya suatu peristiwa yang diberitakan. Antusias ini tidak terlepas dari Instagram sebagai wadah akun lambe turah dalam menyebarkan informasi mereka lebih luas di Indonesia. dengan hadirnya siapapun untuk dapat saling share informasi secara bebas tanpa harus mengikuti kode etik jurnalistik. Sehingga Saat ini kantor berita terbesar di Indonesia bukan lagi Antara, tetapi instagram (Erlangga, 2019). Fenomena ini menegaskan bahwa strategi lambe turah dengan memanfaatkan instagram sebagai wadah penyampaian informasi berhasil membawa mereka mendapatkan kepercayaan masyarakat melalui konten-konten yang ditampilkan.

Pemberitaan informasi di Lambe Turah tergolong nyentrik dan jauh berbeda dengan judul maupun isi yang biasanya disampaikan oleh sebagian besar media massa dalam menyebarkan informasi ke publik. Kebebasan lambe turah dalam menyampaikan informasi dikarenakan mereka hanya sekelompok orang yang memanfaatkan Instgram sebagai wadah menyebarkan informasi, akan tetapi mereka bukan media, bukan bagian dari pers, tidak memiliki badan hukum, tidak memiliki kantor, mereka hanya memiliki konten-konten dan menghasilkan uang (Restu, 2019). Sehingga mereka tidak memiliki kewajiban untuk mengikuti kode etik jurnalisitik dalam usaha penyampaian informasi. Berbeda dengan media massa biasanya, lambe turah terkesan lebih personal, sangat cepat dalam menyampaikan informasi karena tidak melalui proses editing, terkesan sangat rileks dengan menggunakan bahasa sehari-sehari yang mudah dipahami oleh masyarakat luas, komunikasi yang lebih interaktif (Armando, 2019). Penjelasan ini 
menjadikan lambe turah memperoleh khalayak yang solid sebagai pengikutnya. Pertimbangan diatas dibuktikan dengan $37,3 \%$ dari keseluruhan responden dengan prosesntase tertinggi yang berasumsi bahwa akun lambe turah memiliki khas tersendiri dibanding dengan mesia- media lain. Pada respon penerimaan informasi, netizen cenderung sebatas penasaran. Hal ini dibuktikan dengan $77,3 \%$ responden penasaran ketika menerima informasi dari Lambe Turah.

Postingan yang ditampilkan oleh lambe Turah lebih banyak tidak menampilkan sumber informasi yang jelas, bersifat anonimitas, sehingga akurasi data dan pertanggungjawaban informasi ke publik masih dipertanyakan. Berdasarkan hasil survey, sebanyak 39,1\% respon atau sebanyak 43 orang mengatakan bahwa informasi yang disampaikan oleh lambe Turah tidak dapat dipertanggung jawabkan, dan lebih cenderung pada pelemparan opini semata. Fenomena ini sebetulnya menunjukkan bahwa informasi yang disajikan oleh lambe Turah cenderung anonim. Anonimitas atau menyembunyikan identitas merupakan bentuk karakter dari era digital, dan justru hal ini lah yang memberikan ruang bebas untuk berekspresi bagi masyarakat (Setu, 2019), karena saat ini masyarakat lebih nyaman untuk menjadi anonim ketika menerima maupun menyampaikan informasi ke media. Meski demikian admin lambe turah tidak menampik jika banyak sumber informasi yang mereka peroleh berasa dari keluarga dekat maupun orang-orang yang memiliki hubungan dengan figur yang diberitakan dengan kepentingan tertentu (Restu, 2019 ).

Postingan Lambe Turah yang terbilang unik turut memberikan dampak secara emosional kepada netizen atau masyarakat pengikutnya, sebanyak 44 responden atau sekitar 40\% menganggap informasi yang disampaikan Lambe Turah mengandung unsur provokasi. Hal ini dikarenakan caption Lambe Turah tidak menunjukkan data yang jelas dari informasi yang ditampilkan, sehingga memunculkan asumsi-asumsi baru, dan tidak ada interaksi balik atau klarifikasi yang dilakukan oleh lambe turah kepada publik. Pada level ini pemerintah sebatas mewadahi setiap konten-konten akun media sosial pada peraturan menteri tentang pemblokiran konten yang dianggap merugikan orang lain dan bangsa. Dengan profokasi yang dilakukan, netizen Lambe Turah lebih memilih untuk mengklarifikasi ketika ada informasi yang disampaikan oleh Lambe Turah.

\section{Persepsi Netizen terhadap Lambe Turah dalam Perspektif Filsafat Sosial}

Lambe Turah adalah salah satu akun media sosial yang menjalankan penyebaran informasinya dengan cara mempertahankan anonimitas. Anonimitas merupakan salah satu akibat dari berkembangnya teknologi komunikasi. Teknologi komunikasi berupa internet mengakibatkan biasnya batas wilayah dan batas negara dan berakibat pada kebebasan pada masyarakat unuk menyampaikan pendapat dan pandangannya. Khususnya dengan keberadaan media sosial, masyarakat semakin leluasa untuk menyampaikan pandangan atau menyampaikan apa yang diinginkannya.

Permasalahan atau persoalan yang menarik menurut masyarakat disampaikan dalam bentuk argumentasi di media sosial, termasuk saat masyarakat tersebut menanggapi postingan dari akun Lambe Turah. Lambe Turah memposting suatu informasi khususnya mengenai kehidupan selebriti, dengan melalui pemantauan terhadap akun selebriti atau tokoh tersebut, dapat juga melalui masyarakat yang mengirimkan suatu informasi di antaranya dengan cara mengirimkan direct message ke akun Lambe Turah. Habermas berargurmen bahwa ada tiga kompleks yang tidak bisa dirasionalisasikan, sehingga juga sulit mendapatkan pengetahuan yang sahih untuk mencapai konsensus. Menurut Habermas, sikap mengobjektifkan dunia batin, sejauh sebagai subjektivitas, tidak bisa menghasilkan pengetahuan yang bisa dipelajari. Sikap ekspresif terhadap 
interaksi sosial, misalnya dalam bentuk kontrakebudayaan, tidak membentuk struktur yang dapat dirasionalisasikan. Gerakan kontrakebudayaan, menurut Habermas, tidak menghasilkan pengetahuan secara otonom, melainkan tergantung (parasitis) pada inovasi kompleks-kompleks lain (Hardiman, 2009).

Media sosial jika melalui pendapat dari Habermas dapat dipahami sebagai suatu ruang ekspresi masyarakat. Media sosial adalah tempat berekspresi seseorang untuk menyampaikan apa saja yang terdapat dalam pikirannya, baik dengan membuat postingan ataupun memberikan komentar melalui akun media sosialnya. Terlebih di dalam media sosial, anonimitas dapat menjadi pilihan bagi masyarakat tersebut. Anonimitas menjadi sesuatu yang penting bagi seseorang atau kelompok di dalam masyarakat yang mungkin saja akan menghadapi resiko besar jika turut terlibat dalam ruang media sosial sebagaimana identitas aslinya. Di dalam media sosial, seseorang yang diwakilkan dalam sebuah akun dilihat bukan dari latar belakang dan identitas pribadinya, melainkan dilihat dari bagaimana pendapat yang ia sampaikan dan bagaimana ia melogikakan pendapatnya.

Kebebasan berpendapat dalam media sosial dapat dikatakan terlindungi dari suatu sistem hingga batas tertentu, sebagaimana yang tertulis di dalam UU ITE yang mengatur tentang Informasi dan Transaksi Elektronik. UU ITE menjatuhkan sanksi khususnya terhadap konten atau pendapat yang menyinggung SARA atau belum terdapat pembuktian kebenarannya. Artinya, di luar hal tersebut selama masih dalam cakupan opini atau memiliki bukti untuk mendukung argumentasinya, maka sah saja bagi masyarakat untuk berpendapat.

Jika melihat pada penjelasan bagaimana persepsi netizen terhadap akun Lambe Turah, maka dapat kita lihat bahwa sebagian besar alasan masyarakat melihat atau mengikuti akun Lambe Turah adalah karena adanya rasa penasaran terhadap pemberitaan tersebut. Lambe Turah merupakan akun yang cenderung memposting suatu informasi secara tidak teratur, seringkali diposting secara apa adanya seperti bentuk asli informasi tersebut didapatkan, ditambah caption yang membuat masyarakat membangun opininya sendiri terhadap kebenaran suatu informasi. Dengan bentuk postingan dan caption yang demikian, masyarakat merasa diberikan peran untuk mengembangkan opininya sendiri dan melalui kolom komentar masyarakat bebas mengemukakan pendapat dan saling berargumentasi dengan masyarakat lainnya.

Sikap ekspresif memiliki karakter yaitu sebagai hubungan estetis-moral dengan lingkungan yang tidak diobjektifkan, merupakan suatu bentuk pernyataan diri, dan hubungan spontan indrawi dengan diri (Habermas, 1984). Sikap ekspresif datang dari tiap individu dalam masyarakat dengan perwujudan yang berbeda-beda, dengan kata lain di dalam suasana media sosial reaksi setiap masyarakat dapat berbeda terhadap satu informasi yang sama, dan memungkinkan untuk membentuk dua reaksi berbeda terhadap satu berita. Media sosial dimungkinkan untuk menjadi tempat berekspresi masyarakat, dan sebagaimana yang telah disampaikan sebelumnya sikap ekspresif bukanlah suatu sikap yang dapat dirasionalisasi, termasuk di dalamnya anonimitas sebagai bentuk berekspresi masyarakat dianggap sebagai salah satu ciri interaksi media sosial yang sah saja dipilih oleh masyarakat.

Namun sikap ekspresif yang diwajarkan di dalam interaksi media sosial ini menjadi suatu permasalahan karena justru dianggap sebagai wujud rasionalitas masyarakat. Rasionalitas dipahami sebagai suatu keadaan yang bersifat relatif oleh masyarakat. Masyarakat tidak sepenuhnya menyadari bahwa ekspresi dalam menyampaikan dan menanggapi suatu informasi di dalam media sosial mengarahkan pada kecenderungan 
untuk meninggalkan rasionalitas. Dapat kita lihat peristiwa yang viral di masyarakat, baik pembahasan tentang selebriti maupun permasalahan yang berkaitan langsung dengan masyarakat seperti kisruh politik seringkali merupakan bentuk berlebihan dari peristiwa yang sebenarnya terjadi. Saat viralnya peristiwa tersebut sesuai atau dianggap mendukung pemikirannya tentang suatu keadaan atau peristiwa, terlebih jika berkaitan dengan pandangan besar seperti pandangan politik dan ideologis, sebagian masyarakat cenderung mempercayai dan menyebarkannya. Kebenaran suatu informasi bukan dilihat dari seberapa rasionalnya informasi tersebut, tetapi dilihat dari siapa yang menyampaikan.

Lambe Turah dalam hal ini dilihat sebagai akun media sosial yang independen dan terlepas dari otoritas lebih tinggi. Lambe Turah yang awalnya hadir dan memberikan informasi mengenai selebritis, mulai merambah ke permasalahan lain, apa saja selama terbukti terjadinya peristiwa dan berpotensi memantik reaksi masyarakat, dapat disebarkan oleh akun tersebut.

\section{PENUTUP}

\section{Kesimpulan}

Lambe turah merupakan media pemberitaan melalui instagram dengan mengandalkan sumber anonimitas dari netizen sebagai penyampai sumber informasi. Kecenderungan netizen terhadap isu-isu kontroversial menjadikan lambe turah berhasil merebut ceruk pasar pemberitaan dari media mainstreem. Terbukti tak kurang dari 6 juta pengguna akun instagram ini telah berdiri dan dikembangkan sejak tahun 2015. Sikap lambe turah yang menerima konten dari warganet dengan dapat dibuktikan, membuat netizen merasa terlibat dan terwadai untuk ikut mengirim konten yang menarik dan diminati masyarakat. Sehingga informasi dari lambe turah tidak jarang menjadi rujukan bagi beberapa media mainstream

Respon netizen terhadap hadirnya Lambe Turah sebagai media pemberitaan membuktikan bahwa keterlimpahan informasi yang ada di sekitar masyarakat melalui media sosial tergantung sesuai dengan kecendurangan masing-masing. Tinggginya antusiasme netizen terhadap setiap sajian informasi lambe turah menempatkan lambe turah sebagai media yang berhasil menarik perhatian masyarakat. Branding lambe turah dimata netizen sebagai media yang bebes, tidak terikat dengan pers dengan pembawaan informasi yang terkesan menyesuaikan bahasa sehari-hari masyarakat. Kebebasan yang dimiliki lambe Turah dibarengi dengan anonimitas sebagai sumber berita, sehingga $39,1 \%$ netizen berpendapat bahwa informasi lambe turah tidak dapat dipertanggungjawabkan. Meskipun pada kenyataannya masyarakat lebih nyaman untuk memilih sebagai anonim. Pada taraf akhir, lambe turah telah memberikan sumbangsihnya dalam mempengaruhi psikis netizen secara emosial melalui informasi yang cenderung profokaitf.

Bagi Habermas, media sosial merupakan ruang ekspresi masyarakat. Anonimitas dalam media sosial menjadi penting bagi seseorang atau kelompok sebagai sarana alternatif bertemunya dengan resiko lebih besar dibanding dengan identitas asli. Besarnya antusias masyarakat terhadap Lambe Turah karena rasa penasaran terhadap pemberitaan tersebut menyampaikan suatu informasi secara tidak terstruktur. Keterlibatan masyarakat dalam pola pemberitaan Lambe Turah selain sebagai sumber informasi, juga terwadahi dengan adanya kolom komentar untuk mengemukakan pendapat. Rasionalitas dipahami sebagai suatu keadaan yang bersifat relatif oleh masyarakat namun kspresi 
yang ditunjukkan masyarakat di media sosial cenderung meninggalkan sikap rasional. Masyarakat cenderung mempercayai dan menyebarkan informasi yang dirasa mendukung pemikirannya seperti ideologi, pandangan politik, maupun kondisi sosial sekitar.

\section{Saran}

Hasil penelitian ini dapat dijadikan bahan pertimbangan bagi pemerintah khususnya kemkominfo dan jajarannya dalam memutuskan regulasi mengenai penyebarluasan informasi sehingga tidak membatasi kebebasan berpendapat namun juga tetap kondusif dengan memahami bahwa hal terpenting dalam ruang publik ialah rasionalitas.

Bagi para peneliti, akademisi dan praktisi media informasi dan komunikasi hasil penelitian ini dapat dilanjutkan untuk kepentingan kajian pengembangan strategi komunikasi kotemporer.

\section{DAFTAR PUSTAKA}

Anton Bakker, A. C. Z., 1990. Metodologi Penelitian Filsafat. Yogyakarta: Kanisius.

Armando, A., 2019. pandangan pakar komunikasi terhadai media sosial (lambe turah) [Interview] (Jumat April 2019).

Bahasa, B. P. d. P., 2016. KBBI Kemendikbud. [Online] Availableat:https://kbbi.kemdikbud.go.id/entri/Terkenal [Accessed 22 November 2018].

Erlangga, A. M., 2019. Pola Pemberitaan Lambe Turah [Interview] (Rabu April 2019). Febrianto,S.,2017.Tribunseleb.[Online]Availablea HYPERLINK "http://www.tribunnews.com/seleb" Ih t:http://www.tribunnews.com/seleb /2017/11/21/ [Accessed 23 November 2018].

Habermas, J., 1984. The Theory of Communicative Action Jilid 1. Boston: Beacon Press. Hardiman, F. B., 2009. Menuju Masyarakat Komunikatif. 2nd ed. Yogyakarta: Kanisius.

Hamidi, 2008. Metode Penelitian Kualitatif. Malang: UMM Press.

Kurniawan,T.S.,2016.VIKKOMPAS.[Online]Availableat:https://vik.kompas.com/selebgr am/[Accessed 23 November 2018].

Lechte, J., 2004. 50 Filsuf Kontemporer. Yogyakarta: Kanisius.

Mabweazara, H., 2011. Between the newsroom and the pub: The Mobile phone in the dynamics of everyday mainstream journalism practice in the zimbabwe. Jurnalism, Volume 12(6), pp.692-707.

Prajarto, N., 2018. Netizen dan Infotainment:Studi Etnografi Virtual pada Akun Instagra HYPERLINK "mailto:@Lambe" \h m @Lambe Turah. Jurnal Ilmu Komunikasi, Volume 15, pp. 33-46. BIBLIOGRAPHY

Prof. Dr. Nyoman Kutha Ratna, S., 2016. Metodologi Penelitian. II ed. Yogyakarta: Pustaka Pelajar.

Restu, 2019 . Investigasi Tirto dengan Lambe Turah [Interview] (Kamis April 2019 ).

Restu, 2019. investigasi Tirto dengan Lambe Turah [Interview] (Kamis April 2019).

Sari,W.A.P.,2016.JurnalAssia.[Online]Available https:/ HYPERLINK "http://www.jurnalasia.com/opini/viral" \h /www.jurnalasia.com/opini/vir al [Accessed Jum'at November 2018].

Setu, F., 2019. Regulasi Tentang Media Sosial [Interview] (24 April 2019).

Setu, F., 2019. Regulasi tentang media sosial [Interview] (Kamis April 2019). 
E-ISSN : 2656-4718

P-ISSN : 2302-8106

Jurnal Ranah Komunikasi (JRK)

Volume 2 Nomor 02 Tahun 2018

Setu, F., 2019. Regulasi tentang media sosial [Interview] (Rabu April 2019).

Subijanto, R., 2014. Ruang Publik Dulu dan Sekarang. [Online] Available at: $\quad$ https://indoprogress.com/2014/04/ruang-publik-dulu-dansekarang/

[Accessed 14 Mei 2019].

Wirgadireja, A. $\quad$ T., 2017. Vice Indonesia. [Online] Available at: https//www.vice.com/id_id/article/wnvvmb/hegemoni-lambeturah-atas-dunia-maya-indonesia

[Accessed 15 Mei 2019]. 